\title{
SILNÁ EVROPA? EKONOMICKÁ KRIZE A EKOLOGICKÉ ZÁVAZKY
}

\author{
ZDENKA SOKOLIIČKOVÁ, GAUDENZ ASSENZA a ALIAKSANDR MARTYNAU
}

\section{1. Úvod}

\author{
Motto: „Není už dost ,příznaků doby', které naznačují, \\ že je třeba nový začátek?" \\ Ernst Friedrich Schumacher
}

Evropská ekonomika je uprostřed své nejhlubší recese od 30. let, s reálným poklesem HDP o $4 \%$ v roce 2009, což je nejvýraznějším snížením v dějinách EU. Přestože se v poslední době objevují známky zlepšení, obnova zůstává nejistá a vratká. [Buti 2009]

Těmito slovy je uvozen dokument s názvem Economic Crisis in Europe: Causes, Consequences and Responses, kterýv roce 2009 vydala Evropská komise (EK) za účelem představení své koncepce řešení globální ekonomické krize. I když zpráva nenabízí hloubkovou analýzu tématu, lze z ní získat rámcový přehled o všeobecném vnímání probíhajících procesů.

Řetězec událostí, který se v EU spustil, není v žádném prrípadě pouze ekonomického charakteru. Ekonomika nemůže být věcně analyzována, je-li oddělena od politiky, která ovlivňuje bezpočet oblastí klíčových pro život občanů, od kulturního rozvoje přes sociální podmínky až ke stavu životního prostředí. Porozumění souvislosti mezi globální ekonomickou krizí a jejími četnými krátko- i dlouhodobými důsledky pro kvalitu života v EU nám umožní vyvarovat se pouze ekonomizujících úvah, které neosvětlí ani složité kořeny krize, ani potenciální řešení. Širší pohled na problém nejen lépe odhalí skutečná ekonomická východiska naší společnosti, ale umožní také přesněji určit výhledy regionu do budoucna.

Z řady aspektů, které se nabízejí ke studiu, chceme-li se zabývat globálními ekonomickými trendy patrnými v EU, volíme jejich vliv na životní prostředí, či přesněji řečeno regionální ekologické závazky. Naše uvažování se nicméně neomezí pouze na opakování všeobecných tezí o provázanosti ekonomické krize a environmentálních cílů EU. Ačkoli je pravděpodobné, že oslabená ekonomika bude znamenat snížené výdaje např́ílad v oblasti regulace změny klimatu, logika poznání této závislosti nepředstavuje systémové odůvodnění takového zpětného chodu. Spiše je postavena na mělkém truismu, podle nějž je v okamžiku potřeby šetřit na místě neinvestovat nadále do aktivit, jejichž ukončení nepředstavuje okamžité ohrožení fungování společnosti. Chceme se vyhnout podobně povrchním závěrům a zaměřit se na následující otázku: Kdyby v sobě idea „silné Evropy" skutečně zahrnovala hluboké environmentální souvislosti, bylo by politicky a společensky uskutečnitelné je pominout ve chvíli ekonomického úpadku? 
A můžeme jít ještě dál, s tvrzením, že globální ekonomická krize je souběžná s krizí ekologickou, přičemž obě jsou zapříčiněny chybnou představou o podstatě „síly“, která má být klíčovou charakteristikou sjednocené Evropy.

Jádrem našeho tématu je (ne)kompatibilita ekonomie a ekologie. Díváme-li se na věc z pohledu ekonomické a environmentální politiky EU, otevírá se problém údajných a skutečných priorit instituce.

Britští výzkumníci Jon Burchell a Simon Lightfoot přesvědčivě argumentují, že „samotné vlastní principy EU aktivně přispívají k prohlubování environmentálních problémů v Evropě, spíše než aby nabízely účinná řešení. Jak může EU jednat efektivně, pokud je výchozí příčinou mnoha těchto problémů vzorec nepřerušovaného ekonomického růstu a průmyslového rozvoje, na něž se EU vždy zaměřovala především?" [Burchell, Lightfoot 2001: 12]

Bylo by nicméně příliš zjednodušující, kdybychom konstatovali, že EU bude nucena nedostát svým ekologickým závazkům, nebot je vystavena silným tlakům z ekonomické sféry, způsobeným domácími i externími tenzemi. Soustřed’me se spíše na fenomén, který Burchell a Lightofoot označují jako vlastní principy EU, a pokusme se odpovědět na otázku, zda EU neriskovala recesi s environmentálními důsledky kvůli svému vnitřnímu nastavení.

At tak či onak, vztah mezi ekonomikou a životním prostředím patři k nejnaléhavějším tématům dneška. Jedním z cílů tohoto článku je odhalit, zda je pravděpodobné, že současná ekonomická krize prohloubí již existující diskrepanci mezi tím, co je ekonomy chápáno jako prospěšné, a tím, co je prospěšné pro životní prostředí, v němž lidská společnost naplňuje svoji existenci. Jinými slovy, studujeme zde rozdíl mezi myšlenkou ekonomicky konkurenceschopné Evropy a myšlenkou silné a zdravé Evropy v globálním (přírodním, společenském, ekonomickém) kontextu.

Nemůžeme ovšem ignorovat kladné trendy soudobého vývoje. Lze předpokládat, že ztenčené rozpočty způsobí zpomalení výroby a tím také snížení uhlíkových emisí, a že povedou k opatrným výdajům v oblasti dopravy či spotřeby energie. [Klare 2008] Takové tendence mohou dočasně odlehčit břemeno, které naše společnost na životní prostředí vkládá, jak to ostatně často prezentují média:

Ekonomická krize možná znamená strádání lidí po celé Evropě a ve světě, v rozsahu, který jsme nezažili již několik desetiletí. Chceme-li však najít něco pozitivního na neutěšeném stavu světové ekonomiky, pak je to fakt, že kolaps průmyslové mašinerie povede k propadu množství vypouštěných uhlíkových emisí, které nyní překračují veškeré vládní limity. [Phillips 2009]

Jakkoli může být taková domněnka pravdivá, nelze se spoléhat na neudržitelná a provizorní opatření, aniž bychom revidovali naši životní strategii vůči světu, jejž obýváme. Jak naznačuje úvodní citát E. F. Schumachera, zrání času je procesem, jemuž musíme věnovat pozornost, pokud si nechceme jedinečnou př́iležitost pro změnu nechat protéct mezi prsty. Ambicí autorů tohoto článku je přeformulování konceptu „silné Evropy“ na základě zkušenosti ekonomické krize. Jak uvidíme dále, nárazové fiskální úpravy (navíc prohlubující neudržitelnost veřejných rozpočtů) nestačí, má-li opravdu „EU z krize vyjít posílena“ [EC 2008a: 7]. 


\title{
2. Současná situace: Ekonomické a environmentální nejistoty
}

\author{
Motto: „V krizi naší doby nejde o finanční či ekonomický krach. \\ Ve skutečné krizi naší doby jde o krach intelektuální: krach \\ ustáleného ekonomického myšlení.“ \\ Otto C. Scharmer
}

Evropa, ve které žijeme, je zdánlivě jedna a sjednocená. Ovšem již první bližší pohled na analýzy různých evropských aktérů momentálního stavu toto zdání vyvrací. Chápání dnešních procesů se značně liší, jak postupujeme od oficiálních orgánů EU (např. EK) přes vládní instituce a komerční subjekty k nezávislým organizacím a iniciativám občanské společnosti.

Detailně se na tyto rozdílné pohledy zaměříme ve čtvrtém oddílu článku. Nyní se však pokusme shrnout základní oficiální informace o obou studovaných oblastech, což nám poslouží jako data pro vlastní analýzu.

Abychom mohli zhodnotit stav ekonomiky a životního prostředí, musíme vzít $\mathrm{v}$ úvahu množství faktorů a proměnných. Vyčerpávající seznámení však tento článek nabídnout nemůže ani $v$ jedné ze sfér.

Navíc lze těžko hovořit o ekonomice jednoho regionu, byt poměrně rozsáhlého, vzhledem ke globalizované povaze světových trhů. Vzájemná souvislost je ještě patrnější v oblasti životního prostředí. Když v roce 2007 praskla spekulační bublina ve Spojených státech amerických, trvalo jen rok, než se recese přelila do Evropy. V př́padě vážných ekologických havárií, jako byl např́klad únik ropy z vrtu společnosti British Petroleum (BP) v roce 2010 či únik radiace $\mathrm{z}$ jaderné elektrárny ve Fukušimě v Japonsku v roce 2011, byly důsledky patrné ještě rychleji. Jen sotva můžeme mluvit o udržitelném ekonomickém rozvoji pouze $\mathrm{v}$ jedné části světa a totéž platí pro zdravé životní prostředí. $\mathrm{Z}$ vysokého stupně provázanosti a stále rostoucího potenciálu moderní technologie a průmyslu (včetně potenciálu působit škody bez ohledu na hranice států, jak se ukázalo při př́ívalech kontaminovaného červeného bláta rozšířeného $\mathrm{z}$ odkalovací nádrže hliníkárny u města Ajka v Madarsku v roce 2010) vyplývá, že cesta k př́znivému stavu jak ekonomiky tak životního prostředí vede výlučně přes kolektivní akci.

Navzdory těmto omezením můžeme poskytnout alespoň rámcový přehled informací dostupných z oficiálních zpráv, nejprve v celosvětové perspektivě a následně se zvláštním zřetelem na Evropu.

Začněme se všeobecnou charakteristikou posledních dvou dekád, údobí, které začalo nadejjí vkládanou do přechodu $\mathrm{k}$ demokracii v mnoha zemích a stoupajícího zájmu o environmentální otázky, a které skončilo nejhlubší recesí od 30. let 20. století a několika závažnými ekologickými katastrofami. Takto situaci vystihuje OSN:

Svět se od roku $1987^{1}$ radikálně proměnil - společensky, ekonomicky a ekologicky. ... Celosvětově se HDP per capita (parita kupní síly) zvýšil z 5927 US\$ v roce 1987 na 8162 US\$ v roce 2004. Růst však byl mezi světovými regiony distribuován ne-

\footnotetext{
1 V roce 1987 byla Světovou komisí pro životní prostředí a rozvoj vydána zpráva Naše společná budoucnost, známá také jako Brundtlandové zpráva.
} 
rovně. ... Faktory proměny jako populační růst, ekonomické aktivity a vzorce spotřeby zvýšily tlak na životní prostředí. Vážné a dlouhodobé překážky udržitelného rozvoje přetrvávají. [GEO-4 2010: 3-4]

V roce 2010 vydal MMF svoji pravidelnou zprávu s názvem World Economic Outlook (WEO): Recovery, Risk, and Rebalancing. Dokument je uvozen následujícími slovy:

Prozatím pokračuje ekonomická obnova podle očekávání, ačkoliv riziko dalšího propadu zůstává vysoké. Většina rozvinutých a některé nastupující ekonomiky se stále potýkají se zásadními reformami, včetně potřeby posílení účetní rozvahy domácností, stabilizace a následného snížení veřejného dluhu, a celkového oživení finančního sektoru. [IMF 2010: 1]

Přestože tedy tři roky po propuknutí krize existovala shoda ohledně jejích hlavních př́čin a dopadů, nebyly podniknuty žádné kroky k odstranění strukturních nedostatků globální ekonomiky. Patř́ k nim nestabilita, spekulativní potenciál finančních trhů či praxe tzv. otáčivých dveří mezi Bílým domem a Wall Street, kde je personálně propojen vysoký byznys a politické vedení, a její analogie v jiných státech po celém světě.

Reč́ ćísel, míra růstu HDP v EU byla odhadnuta na $3,1 \%$ v roce $2007,0,7 \%$ v roce 2008, přičemž v roce 2009 došlo k ostrému propadu o 4,1\%. [CIA 2010] Pokud jde o HDP, lze zaznamenat známky zlepšení. Ve druhém kvartálu roku 2010 vzrostla ekonomika EU-27 o $2 \%$ [Eurostat News Release 148/2010]. Existují však tři hrozby pro křivku HDP: nezaměstnanost způsobující ztrátu profesních dovedností, ztenčující se zásoby vybavení a infrastruktura, a zbrzděná inovace kvůli omezeným investicím [Buti 2009].

Kromě mdlého růstu výroby a zmraženého trhu práce je pozornost upřena na dluh veřejných financí. „Bude-li dodržen současný trend, veřejný dluh v eurozóně dosáhne $100 \%$ HDP v roce 2014." [Buti 2009] V rámci EU-27 jako celku se veřejný dluh zvýšil z $61,6 \%$ v roce 2008 na 73,6\% o rok později. [Eurostat News Release 55/2010]

Obecně lze evropskou ekonomiku charakterizovat jako stagnující, přičemž některé členské státy vykazují známky pomalého a nejistého zlepšení. Dosahují jej př́snými úspornými opatřeními, jejichž hlavním cílem je návrat k údajné stabilitě před začátkem krize.

Výzva pro politiky spočívá ve vytvoření koordinované strategie, jejíž součástí budou zásadní úpravy stávajícího systému vedoucí $\mathrm{k}$ návratu ke zdravému střednědobému růstu. [IMF 2010: vii; zvýraznění Z. S.]

Ztráta rovnováhy, kterou EU utrpěla v roce 2009, a panika vyvolaná široce diskutovanou krizí v Řecku² v roce 2010 se zdají být překonány. Veřejnost očekává uklidňující zprávy o sice pomalém, ale jistém návratu starého řádu. ${ }^{3}$ Ovšem i o krátkodobém zlepšení je informováno s nejvyšší obezřetností:

Přirozeně je v této souvislosti třeba vzpomenout rovněž problémy v Irsku, Španělsku, Itálii a Portugalsku. Na summitu EU v ř́inu 2010 prohlásila kancléŕka Spolkové republiky Německo Angela Merkelová, že ,je důležité vytvořit pro Evropu jednoznačnou kulturu stability. To je konečným cílem soudržnosti EU. Evropa nás činí silnými, ale tato Evropa potřebuje pravidla.“ [Wissenbach, Heritage 2010] 
Celkově současný trend připomíná situaci, $v$ níž ještě udržitelnost momentální ekonomické obnovy v Evropě nemůže být potvrzena, a to i přes známky oživení růstu HDP. Nedávná krize vedla k prohloubení nerovnováhy ve veřejných financích a míry dluhu za rok 2009, s negativními důsledky i pro rok nadcházející. [Eurostat 2010: 5]

Přesuneme-li se k oblasti životního prostředí, situace je sice $\mathrm{v}$ tuto chvíli méně dramatická, přinejmenším na evropském kontinentu, avšak jen stěží lépe předpověditelná či udržitelná. Přestože panují neshody ohledně intenzity, dopadů a závažnosti ekologických změn, které nastaly hlavně v průběhu druhé poloviny 20. století, nedá se popřít fakt celosvětové dynamické proměny prírodních podmínek.

Zpráva GEO-4 uvádí, že situace v Evropě se vykazuje dvojznačností, pramenící z kombinace neekologického životního stylu a vyspělého stupně ekologických závazků:

V Evropě přispívají rostoucí př́imy a počty domácností k neudržitelné výrobě a spotřebě, zvýšené konzumaci energie a většímu množství vypouštěných emisí skleníkových plynů, nevyhovující kvalitě vzduchu ve městech a problémům v dopravě. ... Od roku 1987 byly sice emise skleníkových plynů z energetického sektoru v západní Evropě sniženy, ale celkově od konce 90 . let v rámci celého regionu stoupají, částečně proto, že vzrůstající ceny palivových plynů způsobily návrat k uhlí coby klícovému zdroji energie. $V$ poslední době vnesl zvyšující se zájem veřejnosti o téma, podpořen zdražováním energie, na politickou scénu otázku klimatických změn. Navzdory jistému pokroku i nadále působí špatná kvalita vody a vzduchu ve městech značné problémy v určitých částech regionu, negativně ovlivňující zdraví a kvalitu života lidí. ... Emise látek znečištujících vzduch souvisí s potřebou větší mobility. EU úspěšně prosazuje príisnější kontrolu znečišsění $z$ dopravních prostř̌edků. Zemědělství v okrajových oblastech je pod tlakem a trpí jak intenzifikací tak nevyužíváním půdy, přičemž oboje přináší důsledky pro biodiverzitu. [GEO-4 2010: 97]

Mezi nejvlivnějšími faktory řídícími environmentální změny je značná pozornost věnována průmyslu, zemědělství a lesnictví, dopravě, energetice a turismu. [GEO-4 2010: 291-356; Burchell, Lightfoot 2010: 91-96] Tyto sektory jsou rovněž pokryty množstvím environmentálních opatření EU. [Baker 1997; Lenschow 2002; Jordan 2002]

Podle publikace vydané Eurostatem s názvem Energy, transport and environment indicators [Eurostat 2009], která zahrnuje období mezi lety 1996 a 2006, se nejnovější vývoj v EU vyznačuje následujícím:

- nárůst energetické závislosti ${ }^{4} 22 \%$,

- celkový pokles výroby energie o $10 \%$ (jedinými progresivními sektory výroby byly jaderná energie o $9 \%$ a energie z obnovitelných zdrojů o $44 \%),{ }^{5}$

4 Proměnná energetické závislosti indikuje míru, do níž je EU (ne)schopná vyprodukovat energii, již sama spotřebuje. Potřeba energii dovážet se tedy stává ćím dál akutnější.

5 Absolutní čísla nicméně ukazují, že energie z obnovitelných zdrojủ stále tvoří jen nepatrnou část celkového objemu energie, obzvláště ve srovnání s jadernou energií či energií z fosilních paliv. Tyto hodnoty navíc nevypovídají nic o faktu, že paralelní pokles ve výrobě energie a nárůst její spotřeby v EU znamená větší potřebu dovozu z jiných světových regionů, kde je energie vyráběna neekologicky. 
- plánovaný pokles skleníkových emisí o $8 \%$ (cíl EU-27 pro rok 2012; vyhodnocení je komplikované, nebot čísla se výrazně liší mezi jednotlivými členskými státy),

- od roku 2003 pokles celkového množství městského odpadu, avšak množství odpadu na osobu zůstává vysoké (517 kg v roce 2006 v rámci EU-27),

- stabilní nárůst produkce chemikálií, přičemž v roce 2007 bylo $58 \%$ klasifikováno jako toxické,

- rozvoj ochranné krajinné sítě NATURA 2000,

- 297 miliard EUR vybraných na ekologických daních v roce 2006 (2,6 \% HDP EU-27),

- $42 \%$ plochy zalesněno, $60 \%$ ročních přírůstků dřeva způsobilých pro těžbu spotřebováno, $13 \%$ zalesněných ploch EU-27 s ochrannými funkcemi

Pro ucelení obrázku uved’me, že podle předloňské zprávy EEA s názvem Assessing Biodiversity in Europe se dosud nepodařilo zastavit biodiverzitní ztráty. Negativní trend nebyl zastaven i přes ambiciózní cíle, ačkoliv marginálního zlepšení bylo dosaženo [EEA 2010].

\title{
3. „Silná Evropa“ v krizi: Na cestě k řešení
}

\author{
Motto: „Evropa musí znovunastolit růst.“ \\ Richard Baldwin, \\ profesor mezinárodní ekonomie, \\ The Graduate Institute
}

Žába, která vyskočí z vroucí vody, pouze pokud je do ní přímo vhozena, ale která se nechá uvařit k smrti, jestliže je voda ohřívána postupně, je oblíbenou analogií, kterou environmentalisté užívají, chtějí-li si postěžovat na pomalé tempo implementace opatření proti globálnímu oteplování. Ilustruje odhodlanost politiků, mají-li zareagovat na okamžitou hrozbu, a zároveň jejich váhavost, jestliže se situace zhoršuje pozvolna.

Evropa prožívá ekonomický šok od roku 2008. Budeme-li se metafory držet a použijeme-li ji pro ekonomické prostředí, můžeme říci, že se žába usilovně snaží zhasit oheň pod kotlíkem, ale vyskočit $\mathrm{z}$ něj odmítá.

Vystavena recesi, Evropa je zhoršujícím se životním prostředím znepokojena ještě méně než před krizí. $V$ porovnání s jinými částmi světa je ovšem životní prostředí v Evropě stále relativně důstojné. Přestože zde existují lokality, kde je znečištění vcelku závažné (např́ílad rumunské město Copsa Mica, kde do roku 1993 fungovala továrna na výrobu uhelných sazí, nebo nechvalně známá Zóna odcizení v okolí černobylské jaderné elektrárny na Ukrajině), Evropané jsou zatím v zahřívací fázi. Řečeno bez obalu, v Evropě se dosud snadno dýchá, ale těžko platí účty.

Situaci lze interpretovat dvěma způsoby. Bud považujeme ekonomický úpadek za hodný větši pozornosti nežli environmentální výzvy, nebo vnímáme oba fenomény jako stejně urgentní. Je evidentní, že třetí možná interpretace - přednostní péče o ekologické otázky namísto ekonomických - by rovněž měla být zmíněna. Detailněji však rozebírána nebude, protože takový postoj je momentálně v politickém veřejném prostoru nepř́itomný a další diskuse by tedy byla pouze hypotetická. 


\subsection{Vnímání ekonomické a ekologické krize: Nespojité či provázané?}

Poté, co jsme shrnuli základní fakta o ekologické a ekonomické krizi, budeme se v této podkapitole věnovat způsobu, jakým jsou oba procesy vnímány, se zvláštním zřetelem na otázku, zda jde o vnímání spojité či nespojité, včetně srovnání připisované naléhavosti.

Začněme komentářm toho, jak prezident Evropské komise José Manuel Barroso hovořil o daných dvou tématech ve svých projevech z poslední doby. Uvádíme úryvek z proslovu prezidenta Barrosa „Od Kjóta ke Kodani“:

Věc je jednoznačná. Pokračování v nastoupeném směru téměř jistě znamená nebezpečné, možná katastrofické klimatické změny v průběhu tohoto století. ... Lidé na této planetě rozumí rozsahu problému stále více. ... Ale ti s politickou odpovědností je dosud kolektivně nepřesvědčili, že existuje potřebná politická vůle přistoupit k řešením, která jdou ruku v ruce s ekonomickým růstem a trvalou udržitelností. [Barroso 2009]

V roce 2010 prohlásil prezident Barroso o ekonomické krizi následující:

Ekonomická a finanční krize - nejhorší za posledních 80 let - otřásla Evropou a celým světem. ... Krize je pro nás Evropany posledním zvoněním na poplach. Je třeba skutečně sjednocené Evropské unie, abychom mohli z krize vyjít silnější než před ní. ... Ukazuje rovněž, že aktivity na podporu růstu a inovace nebudou dostačovat. Nejprve musí být znovunastolena důvěra. Přeloženo do terminologie ekonomie a financí, Evropská unie má před sebou tři úkoly: stabilizovat, konsolidovat, stimulovat. [Barroso 2010]

Rozdíl ve vnímání obou krizí je tedy nasnadě. Zatímco podle Barrosa existuje široké povědomí o zhoršování životního prostředí, političtí vůdci situaci nevyhodnocují jako kritickou. $\mathrm{V}$ př́padě ekonomické a finanční krize se ovšem dle Barrosových slov titî̌ lídři na vážnosti globálních ekonomických trendů shodují.

Pokud jde o hledání cesty z krize, je EK tradičně aktérem, který usiluje o prosazení inovativních federalistických opatření. ${ }^{6}$ Jak je však jasné z úvodních Barrosových slov, odvaha EU vyrovnat se $s$ ekonomickou krizí by měla spočívat $\mathrm{v}$ těsnějším přimknutí $\mathrm{k}$ principům, které řídí integrační proces. Jinými slovy, aby Evropa znovu získala svou ekonomickou sílu, měla by svědomitě následovat cestu vytyčenou $v 50$. letech minulého století, na úsvitu spektakulárního ekonomického růstu a v době, kdy byly širší ekologické úvahy teprve v zárodku.

Jaká jsou opatření, která takové přesvědčení odrážejí? Zaměřují se na stabilizaci eura, konsolidaci veřejných financí a stimulaci strategických oblastí. Jejich cílem je oživení evropské ekonomiky. Je ovšem nejasné, jak by taková opatření mohla vyřešit krizi, která „není jen ekonomickou či finanční krizí (ale - pozn. Z. S.) též krizí hodnot“ [Barroso

6 Nicméně ty generální direktoriáty (DG), které souvisejí s oblastmi financí, obchodu nebo průmyslu, mají tendenci stát v opozici vủči alternativám. ER, na rozdíl od EK, zastupuje spíše konzervativní neoliberální prrístup, zatímco EP stojí někde uprostřed. 
2010]. Z Barrosových tvrzení vyplývá, že se míjí s důležitým poznáním Lestera Browna obsaženém v jeho práci Svět na hraně: „Hodnoty, které vedly k ekologickému deficitu, jsou týmiž hodnotami, které zapř́íčinily deficit ekonomický" [Brown 2011: 3].

Na ustáleném chápání dnešní ekonomické situace je zvláštní, že uznává jedinečnost příležitosti pro změnu, ale nehledá nové perspektivy jak problém uchopit. Místo abychom se soustředili na př́tomnost, respektive budoucnost, veškerá energie je vynaložena na pokus o poučení z minulosti. Historická zkušenost je bezesporu cenným zdrojem informací pro dnešní politiky. Ovšem otázka, která je stěží kdy položena, je, zda by udržení stávajícího ekonomického systému vůbec mělo být konečným cílem dnešního úsilí. Prozatím je krize chápána jako hrozba pro ideu růstu, a znovunastolení důvěry v tento myšlenkový proud je hlavní ambicí zúčastněných aktérů. Žádné radikální (tedy jdoucí ke kořenům, zásadní), nýbrž pouze konzervativní (tedy zachovávající, stávající stav udržující) řešení se bere v úvahu. Injekce likvidity, vládní podpora finančního sektoru a stimulace globálního toku kapitálu mají být východiskem z krize. [Brown 2011]

Zdá se, že zde narážíme na nesoulad mezi připuštěním skutečnosti, že existující ekonomický systém je chybně nastaven, a mentální uzavřeností společnosti a společenských činitelů vůči paradigmatické změně. V tomto světle se slova prezidenta Barrosa jeví jako podivně bezzubá:

Chceme-li překonat krizi, musíme lidskou důstojnost stavět do centra našich aktivit. Lekce, kterou bychom si měli odnést, je poznání, že ani trh ani samotný stát nemohou zodpovědět palčivé otázky dneška. Přinejmenším stejně tak jako potřebujeme je, potřebujeme všechny síly společnosti, abychom mohli dostát potřebám lidí. [Barroso 2010]

Jestliže je ekonomická krize vnímána jako katastrofální událost s četnými vedlejšími efekty a hovoří se o ní jako o tématu nejvyšší naléhavosti, environmentální úpadek přitahuje pozornost veřejnosti ve dvou př́padech: bud' dojde k ekologické havárii, nebo se koná mezinárodní setkání s ekologickým zaměřením.

Domněnka, že pouze nárazové události (spíše než pozvolné procesy) dokáží společnost rozpohybovat, je potvrzena tím, jak odlišně jsou obě krize pojímány. Termín krize není v souvislosti se změnami životního prostředí užíván zcela běžně, a to $\mathrm{z}$ několika důvodů. Zaprvé, zatímco fakt ekonomické krize zpochybňován není, vyskytují se vlivní jedinci i instituce, kteří popírají postupující degradaci životního prostředí.7 Zadruhé, stav životního prostředí, přinejmenším v EU, se ještě nezhoršil do té míry, aby mohl být považován za blízký kolapsu.

Mechanismy, které se uplatňují při ekonomické recesi, a procesy, které doprovázejí environmentální úpadek, jsou všechno jen ne jednoduché. Jejich globální rozměr pouze podtrhuje jejich složitost a přestože nás to jistě nedovede k rychlé a snadné odpovědi, mohlo by být prospěšné podívat se na oba problémy jako na dvě strany téže mince. Ale dívá se na ně takto EU, propagátor myšlenky udržitelného rozvoje?

\footnotetext{
Nejhlasitěǰ̌ími kritiky opatření proti globálnímu oteplování jsou bývalý poradce Margaret Thatcher Viscount Monckton a český prezident Václav Klaus. Nejvlivnějším think-tankem, který nesdílí konsensus ohledně změny klimatu, je Cato Institute.
} 
V roce 2010 se v japonské Nagoyi konalo setkání Spojených národů za účelem vytvoření Úmluvy o biologické rozmanitosti. Událost přitáhla celosvětovou pozornost k ekologickým otázkám a výstupy jednání nebyly zvlášt povzbudivé:

Směr, kterým se vydáme v následující dekádě či dvou, a který bude vytyčen v rámci Úmluvy o biologické rozmanitosti, bude rozhodující pro to, zda bude zachována stabilita ekologických podmínek, na nichž lidská civilizace závisela v posledních 10000 letech, i v prríším století. Necháme-li si tuto př́ležitost uniknout, mnoho ekosystémů na planetě se dostane do nových, zcela bezpř́íladných stavů, v nichž bude jejich schopnost vyhovět požadavkům současných i budoucích generací nejistá. [GBO-3 2010:9]

Japonský tisk představuje EU jako vedoucího aktéra na poli environmentální politiky, bojujícího proti váhavým globálním mocnostem. „Zatímco Evropská unie prosazuje tvrdé cíle zastavení biodiverzitních ztrát do roku 2020, mnoho zemí se staví spíše za mírnější opatření," napsal Asahi Shimbun v úvodníku k Úmluvě o biologické rozmanitosti" [Editorial: Biodiversity Conference 2010]. Profil EU je v tomto ohledu skutečně výjimečný, jestliže jej porovnáváme s ostatními národními a trans-národními entitami. Když však posuzujeme absolutní účinnost aktivit EU, závěry jsou o mnoho skeptičtěǰsí.

V dubnu 2009 EK připustila, že biodiverzitní ztráty na evropském kontinentu nebudou do roku 2010 zmírněny. Nebyl to však zástupce evropských institucí, nýbrž Clairie Papazoglou, ředitelka evropské divize BirdLife International, kdo rozpoznal nutnost chápat životní prostředí a ekonomiku, obojí momentálně v ohrožení, spojitě: „Ti, kteří rozhodují, se musí probudit. V jedenadvacátém století nemohou krátkodobá ekonomická zvýhodnění a soukromé zájmy udávat charakter strategie. $V$ opačném př́padě nezvládneme ani ekonomickou, ani ekologickou krizi." [Environment News Service 2009]

Dalším zdrojem informací o koncepčním pojetí EU tandemu ekonomické a ekologické krize je dokument publikovaný EK v říinu 2008, From financial crisis to recovery: A European framework for action. V celém textu se vyskytuje jeden (sic!) odkaz na environmentální otázky:

EU potřebuje ... investovat do budoucnosti skrze posilování evropské konkurenceschopnosti, a to tím, že budeme pokračovat v ekologizaci naší ekonomiky. Tím bude podporována zaměstnanost i rozvoj technologií, překonány bariéry energetické nezávislosti a dosaženy environmentální cíle. [EC 2008a: 4]

Zatímco v př́ípadě nepříznivého ekonomického vývoje jsou výzvy k okamžitému zásahu obvykle vyslyšeny v podobě závazných opatření, o potřebě jednat v souvislosti s ekologickými problémy se obvykle toliko hovoří. ${ }^{9}$ Je zřejmé, že ekologickým závazkům EU

8 Hlavním výstupem konference je smlouva o Strategickém plánu pro ochranu biologické rozmanitosti do roku 2020, a Nagojský protokol o př́stupu ke genetickým zdrojům a spravedlivém a vyváženém sdílení přínosů plynoucích z jejich využívání. Nezbytné finanční prostředky k dosažení cílů vytyčených $\mathrm{v}$ daných dokumentech, např́klad tzv. Zelený rozvojový mechanismus, však nejsou zajištěny.

9 Viz např. posouzení EEA implementace zelených opatření EU z roku 1997: „EU dělá pokroky, avšak nedosahuje celkového zlepšení kvality prostředí a ještě méně se blíží dosažení udržitelnosti. Pokud se proces ekologické integrace nezrychlí, tlaky na prostředí budou i nadále narušovat potřeby lidského zdraví a často omezenou kapacitu prostředí." [Collier 1997: 2] 
pravděpodobně nedostojí $\mathbf{v}$ obavách $\mathbf{z}$ ekonomických ztrát. Navíc je dnes ještě více než dříve environmentálně mířená akce obhajována na základě ekonomických kritérií. ${ }^{10}$ Takováto argumentace je nejen chybná sama o sobě, ale značí také zásadní zjednodušení celého problému. Idea „ekonomického zviditelnění prŕírody“ [TEEB 2010] ${ }^{11}$ je součástí obrazu světa, který vedl k ekonomickému kolapsu. I když může potřeba měřit, řídit a ekonomicky zhodnocovat $\mathrm{v}$ rámci odpovědného spravování přírodního kapitálu [TEEB 2010] být krokem správným směrem, bude nejspíš stát v cestě jakémukoliv pokusu o paradigmatickou změnu směrem k novým principům, zakořeněným $\mathrm{v}$ absolutní ekologické udržitelnosti.

Na druhé straně existují signály, že by ekonomická krize skutečně mohla být př́ležitostí pro zásadní zelená opatření. Přestože je politická vưle národních politických elit v tomto směru nestejná a podpora ze strany občanů je rovněž nejistá, ${ }^{12}$ oficiální orgány přece jen do diskuse vnášejí nové perspektivy. Například v roce 2007 vznikla iniciativa „Za rámec HDP: Měření pokroku, skutečného bohatství a blahobytu národư “ jako společný projekt EK, EP, WWF, OECD a Římského klubu. ${ }^{13}$

Povědomí o propojenosti obou procesů tedy narůstá, avšak ve veřejném diskursu je důležitost ekonomické recese zdůrazňována na úkor environmentálních problémů.

\subsection{Konkrétní výstupy opatření: Splývající krize, splývající řešení?}

Abychom prověřili naši hypotézu, měli bychom prokázat, že opatření navrhovaná EU ke zmírnění ekonomické krize berou sice ekologické závazky v úvahu, ale jen ve velice omezené míře. Zaměřme se na European Economic Recovery Plan, ${ }^{14}$ dokument vydaný EK a přijatý v listopadu 2008 jako společná strategie EU v boji proti krizi.

Především neexistuje žádný ekvivalent ekonomického plánu obnovy, který by byl výhradně zaměřen na otázky spojené se životním prostředím. Hledáme-li důvod této skutečnosti, nelze se vyhnout problému časového vymezení. Orientace na krátkodobá zlepšení, která je pochopitelná, vezmeme-li v úvahu politickou podstatu EU, není na místě, zabýváme-li se životním prostředím. Jsme svědky zásadního nesouladu časových perspektiv, pokud jde o pokusy definovat možná řešení obou problémů. Neschopnost vyvarovat se této nesourodosti je dána nutností jednat v několika perspektivách najednou a také neochotou vyrovnávat napětí mezi rychle se měnícími ekonomickými potřebami udávanými politickými zájmy a dlouhodobými ekologickými závazky.

10 Viz např výzkumný projekt známý jako TEEB, The Economics of Ecosystems and Biodiversity, podporovaný mimo jiné také EU. Vezměme si následující citaci jako př́ílad: „Existují dvě základní výzvy pro sociální učení, kterým společnost nyní čelí. Zaprvé se stále učíme uchopit koncept hodnoty, jak rozšiřujeme naše pojetí kapitálu tak, aby obsáhl i kapitál lidský, sociální a př́rodní. Uznáním a podporou růstu či zachování těchto kapitálů postupujeme na cestě $\mathrm{k}$ udržitelnosti. Zadruhé se nám stále nedaří vystihnout hodnotu přírody. Př́roda je každodenním zdrojem mnoha hodnot, a přesto většinou zcela obchází trhy a uniká oceňování. Tato absence ohodnocení je, jak se ukazuje, podstatou degradace ekosystémů a zaznamenaného úbytku biodiverzity." [TEEB 2008: 4]

11 Tato zpráva byla zveřejněna 20. 10. 2010 na výše zmíněné konferenci k Úmluvě o biologické rozmanitosti COP10 v japonské Nagoyi.

12 „Přes výsledky sociologických šetření, podle nichž mnozí zastávají zelené postoje, jakmile dojde na lámání chleba, lidé volí podle svých peněženek." [Burchell, Lightfoot 2001:97-98]

13 Více informací na http://www.beyond-gdp.eu/index.html.

14 Dále citováno jako EC 2008b. 
Ekonomická krize není pojímána jako krize ideová, přestože byla jako taková identifikována i oficiálními zástupci EU. Je i nadále chápána jako manažerský zádrhel, který lze vyřešit urychlenými opatřeními, stejně jako lze stroj opravit mechanickým zásahem. Ve chvíli, kdy je takový přístup uplatněn i v otázkách životního prostředí, lze očekávat v nejlepším případě skromné výsledky a selhání v tom nejhorším.

Fakt, že bohaté intelektuální i finanční zdroje jsou investovány do okamžitých záchranných plánů, ale neexistuje seriózní diskuse ohledně obdobného environmentálního padáku, jen potvrzuje domněnku, že zhoršující se kvalita životního prostředí není chápána jako kritická.

„Trhy dokáží reagovat během minut či hodin. Příroda reaguje na ,environmentální plán obnovy' mnohem pomaleji. Zanedbanému habitatu může oživení trvat roky, zatímco snížení emisí skleníkových plynů se dokonce měří na roky a desetiletí. Zásah v zájmu zastavení bankovních bankrotů byl pohotový a drahý, ale záchrana přírodního světa je úkolem, za který teprve bude třeba zaplatit." [Rankin 2009] Co má Jennifer Rankin, reportérka European Voice, na mysli, když ř́ká „pohotový a drahý“? European Economic Recovery Plan, tento evropský ekonomický plán obnovy přijatý v roce 2008, stojí na dvou pilírích a jednom obecném principu. Taktika spočívá ve stimulaci poptávky a povzbuzení důvěry skrze masivní peněžní injekci ve výši 200 miliard EUR (1,5\% HDP). ${ }^{15}$ Tato bezprostřední odpověd' na krizi byla následována programem zaměřeným na takzvané chytré investice do budoucí konkurenceschopnosti EU, jako je např. energetická účinnost, čisté technologie, infrastruktura a prostředí pro inovace. Plán deklaruje solidaritu a sociální spravedlnost jako svůj základní princip. [EC 2008b]

Měli bychom se krátce zastavit u dvou otázek, které se nabízejí, uvažujeme-li o strategii EU na zmírnění dopadů krize. Zaprvé, jaká je kvalitativní povaha plánu obnovy? A jak (pokud vůbec) ovlivňuje životní prostředí?

Občané jsou opakovaně ujištováni, že Evropa míŕi k východu z krize a že stabilita regionu bude dokonce posílena. Skutečně se objevují náznaky zlepšení v některých členských státech, alespoň podle statistických ukazatelů. ${ }^{16}$ EU pokračuje ve svém krizovém managementu, zaměřujíc se především na makroekonomická opatření, strukturální reformy a kontrolní mechanismy pro neukázněné státy. [EU economic governance 2010] Evropští politici jsou si vědomi toho, že finanční systém je v základu chybný a v některých ohledech neetický, ale řešení, která navrhují, se omezují na posílení integrace a vyvarování protekcionismu.

Jak už jsme naznačili, role, kterou ekologické závazky hrají v boji proti ekonomickému úpadku, je ve své filosofické šíři spíše omezená. Mají ovšem napomoci dosažení energetické efektivity a technologické inovace. Lepší infrastruktura, doprava, management odpadu a vodních zdrojů, obnovitelné zdroje energie, zelená výroba a služby, udržitelná spotřeba a nízkouhlíková ekonomika patří mezi ústřední priority. [Council of the European Union 2009]

Zúžení celého problému na zmírňování klimatických změn, revizi energetické politiky a propagaci zelených výrobků je tedy výsledkem limitovaného chápání naší závislosti na životním prostředí. Zavedení environmentálně opodstatněné legislativy spolu s nástroji zacílenými na ekonomickou obnovu však může být krok správným směrem.

15 Během let 2008-2010 věnovala EU ve skutečnosti asi 400 miliard EUR na podporu ekonomiky. [EC 2009a: 2]

16 Podle předpovědi Interim vydané v září 2010 „ekonomická obnova EU, ačkoliv stále nejistá, postupuje rychleji, než se původně předpokládalo. Především růst HDP jak v rámci EU tak eurozóny byl přkkvapivě rychlý ve druhém kvartálu 2010.“ [Interim forecast September 2010] 


\section{Podstata síly}

Motto: „Síla nepochází z fyzických možností.

Pochází z nezdolné vưle.“

Mahatma Gandhi

Představili jsme, jakým způsobem jsou vnímány a řešeny ekonomická a ekologická krize, a nyní se zaměříme na klíčový koncept našeho článku - evropský diskurs síly. Úhlem pohledu, který nabízí nové perspektivy, je podstata síly obsažená v oficiálních výrocích a strategických dokumentech EU. Vyjádříme se postupně ke třem bodům.

Zaprvé, jak lze definovat sílu s ohledem na indicie, které získáme při studiu zmíněných zdrojů? Klíčová slova jako znovunastolení, di̊věra, růst, stabilita, konkurenceschopnost a inovace mohou problém osvětlit.

Zadruhé, do jaké míry je myšlenka síly (kulturní, ekonomické, politické apod.) slučitelná s našimi znalostmi o potřebách životního prostředí? Analýza může odhalit, zda si je EU vědoma oboustranného vztahu mezi ekonomickými opatřeními a environmentálními změnami, a nakolik myslí úpravu stávajícího systému v zájmu udržitelnosti vážně.

Závěrem otevíráme prostor pro nezbytnou revizi podstaty síly. Je třeba však mít na paměti, že př́liš rychlé změny paradigmatu mohou vést ke ztrátě jistoty a sociální anomii. Lidé jsou novým idejím otevřeni jen do určité míry. Za její hranicí je odmítnutí inovace pravděpodobné, protože většinou nejsme ochotni brát zřetel na anomálie, které se vymykají systému, v němž žijeme, natolik, že jej ze základu vyvrací. Bylo by tedy utopické požadovat bezvýhradné opuštění stávajících představ o síle, avšak jejich citlivá redefinice uskutečnitelná být může.

\subsection{Síla jako prostředek}

Chápání síly, jež se odráží v přístupu EU k nejrůznějším aspektům regionálního a globálního vývoje, lze charakterizovat jako instrumentální. Silná Evropa je vykreslena jako entita připravená se postavit konkurentům, vážný soupeř a v ideálním př́ípadě vzor pro méně rozvinuté společnosti. To bezpochyby platí v oblasti environmentálních opatř̌ení; EU sama sebe označuje za průkopníka ekologicky uvědomělých strategií a je za něj považována ostatními regionálními a transregionálními aktéry. Stejné nastavení však lze vysledovat i ve sféře ekonomiky, kdy jsou opatření EU prezentována jako inovativní a následováníhodná v globálním měrítku. „Evropa má dobré předpoklady pro to, aby sehrála aktivní roli při určování nové globální architektury a zajištování jejího správného fungování," uvádí EK ve svém komuniké k protikrizovému plánu. [EC 2008a: 8] Ideologie, kterou zastupuje Komise, zahrnuje koncepci vícerozměrného spravedlivého rozvoje. Tato pozice se značně odlišuje od neoklasického ekonomického myšlení, které nebere v úvahu sociální a ekologická omezení ekonomického růstu. [Cole 2000]

Rozložení moci v bitvě idejí je spíše nevyrovnané. Myšlenkové nastavení společnosti, formované desetiletími jednorozměrnosti, se odráží v institucionalizovaných orgánech výkonné moci, které pracují ve jménu veřejného zájmu. Protože společnost vytváří instituce a tyto zpětně ovlivňují společnost, hodnoty a principy ukotvené v lidské mysli se zrcadlí ve společenském uspořádání, kteréžto se stává nástrojem sebeospravedlnění. 
Komise se tedy v tuto chvíli nachází uprostřed společenského klimatu, které je nastavené tak, aby potvrzovalo platnost existujících vzorců („business as usual“) a navzdory svým ambiciózním cílům se tak nemůže vyhnout pasti této nepružné mentální atmosféry. Smyslem urychleného plánu na záchranu ekonomiky nebylo nic jiného než znovunastolení důvěry v systém jako takový, s ekologickými závazky jako provizorním doplňkem.

\subsection{Rovnováha síly}

Jestliže chápeme dnešní podstatu síly jako vztahování k uspořádání světa před krizí, prostor pro nové vzorce myšlení je více než omezený. Dějiny environmentální integrace v EU jsou dlouhou řadou argumentů a protiargumentů v diskusi o sladění ekonomie a přírody. Můžeme celou věc zjednodušit tvrzením, že ekonomové, politici a environmentalisté se snaží odpovědět na otázku, zda přerozdělení prostředků ve prospěch ochrany životního prostředí musí být nutně doprovázeno zpomalením ekonomického růstu v krátko-, středně- a dlouhodobé perspektivě.

Takové uvažování se opírá o teorii zachování energie, podle níž nárůst v jedné složce systému musí vést k poklesu ve složce jiné. Téma ekonomiky ohrožující prostředí a ekologických závazků (obvykle omezených na snahu o zachování stávajícího stavu) stojících v cestě ekonomickému rozkvětu je tedy výstupem klasické vědecké představy.

Americký ekologický ekonom Herman Daly je známý svou schopností formulovat nové, zásadní otázky. Daly zpochybnil nejen uskutečnitelnost trvalého ekonomického růstu, ale i jeho prospěšnost [Cole 2000; Daly 1996]. Budeme-li následovat tento směr kritických úvah, můžeme analogicky zpochybnit i představu o nezbytnosti zachování energie (potenciálu), a nabídnout hypotézu možnosti souběžného zlepšení. Jestliže se jedna složka systému stane silnější a odolnější, nemusí jiná složka nutně utrpět oslabení. Zde se však dostáváme k podstatnému faktoru povahy růstu.

\section{Síla jako konečný cíl}

Náš návrh kvalitativní revize ideje síly stojí na domněnce, že dokud je síla chápána instrumentálně, nezahrnuje v sobě ohled na potřeby životního prostředí, nebo alespoň ne v dostatečné míře.

Nezávislé nevládní subjekty přispívající do diskuse o ekonomické a ekologické krizi již mnohdy přinesly inspirativní pohledy. Jejich analýzy představují posun od nižších úrovní instrumentality $\mathrm{k}$ vyšším stupňům etiky (a dále).

Vezměme si za příklad tzv. position paper WWF vydaný v září 2010 jako reakci na plán EU snížit negativní dopady ekonomické krize skrze nově navržený komunitní rozpočet:

Reforma rozpočtu EU je základním předpokladem účinné odpovědi na krizi. Evropa a evropské země však nesmějí zopakovat nedávné chyby záchranných opatření a balíčků obnovy bankovního systému, aby byl zachován stávající chod ekonomiky. Mnohé z těchto investic v sobě obsahují potenciální riziko prohloubení ekologické krize. [WWF 2010: 5] 
V této perspektivě se návrat ke stavu před krizí jeví jako problematický, a to nejen pro cenu takového pokusu. Jde především o potřebu hlubokého prřepracování systému, nyní na hranici zhroucení:

Rozpočet EU musí být radikálně reformován tak, aby odrážel rozsah systémové krize před námi. ... EU může a musí převzít odpovědnost. Musí přesvědčit své občany, že jejich peníze budou investovány s rozvahou do ekonomiky budoucnosti, která bude zajištovat život pro ně, jejich děti a další generace. [WWF 2010: 11]

Jak už jsme uváděli dříve, časový horizont změn je obzvláště důležitý pro otázku dvou vzájemně souvisejících krizí. Zatímco se EU jen těžko potýká s rychlými a pružnými opatřeními kvůli byrokratické povaze svých orgánů, je zcela nad její možnosti přijmout právně závazný dokument, jehož dopadů by se žádný ze současných politiků nedožil.

Niže uvedená citace vyjadřuje odhodlání posunout naše úsilí od skromných a politicky korektních kompromisů $\mathrm{k}$ ambicióznějším počinům, které by vedly ke zlepšení lidských podmínek pro život. Evropské sociální fórum jistě nepatř́ k reprezentativním hlasům Evropy, avšak zasluhuje, aby mu bylo nasloucháno:

V novinách se píše o finanční a ekonomické krizi, ale když se rozhlédneme kolem sebe, nevidíme deriváty a finanční trhy - vidíme rozklad společnosti, našeho sociálního a př́rodního prostředí, mezilidských vztahů. ... Musíme bojovat z místa, na kterém stojíme; abychom vytvořili nový svět, potřebujeme také vytvořit novou Evropu a strhnout její opevnění. Těm, kteří rozlišují mezi sociální a environmentální spravedlností, namítáme, že si tyto navzájem neprotiřečí. Jsou a musí být vzájemně se doplňující. Naše představa je dobrý život pro všechny, nikoliv noční můra autoritářské eko-úspornosti. [ESF 2010]

\title{
6. Otevřenost budoucnosti: Na křižovatce myšlenek
}

\author{
Motto: „Měkké a slabé překonává tvrdé a silné.“ \\ Lao-C'
}

V rámci evropské kulturní tradice je běžné přesvědčení, že pokrok a zlepšení mohou být dosaženy prostřednictvím tlaku moci, at už ekonomické nebo politické, která v sobě nese představu síly. Dnešní obrázek „silné Evropy“ zahrnuje Evropu zavádějící opatření na podporu udržitelného rozvoje podloženého synergiemi mezi ekonomickými, sociálními a environmentálními složkami. [EC 2007]

Síla a konkurenceschopnost patří $\mathrm{k}$ vlastnostem akcentovaným $\mathrm{v}$ evropské kultuře. Evropská unie je jejím explicitním následovníkem, čerpající inspiraci z kulturního, náboženského a humanistického odkazu Evropy. [EU 2007] Dialog mezi společností, ekonomií a př́rodním prostředím je řízen $\mathrm{v}$ intencích tohoto institucionalizovaného světonázoru.

Je zřejmé, že EU hrála klíčovou roli v posunu veřejného diskursu, pokud se týče environmentálního výhledu celosvětově. Tento posun však není kvalitativní povahy, jinými 
slovy, nejedná se o kulturní změnu. EU totiž „má všeobecně známé ambice vést zbytek světa na cestě $\mathrm{k}$ řešením, ale sama má problémy s přijetím nutných vnitřních změn. “ [Jordan, Huitema, van Asselt 2010: 4] Vzorce chování jsou mírně pozměněny, u některých jedinců i institucí více než u jiných. Komunita jako celek však pokračuje v nastoleném směru - k instrumentálně „silné Evropě“.

Chybnost logiky síly v jejím tradičním racionalistickém významu je nasnadě, podíváme-li se na jiné regionální mocnosti, které ji přebírají v zájmu maximalizace svého vlastního růstu namísto toho, aby naslouchaly výzvám Evropy k usilování o udržitelnost. I když se Evropa pomalu a bolestně snaží uskutečnit zásadní reformu, drží se i nadále bytostně ekonomické rétoriky „konkurenceschopnosti“. Není proto divu, že se argument síly a růstu západnímu světu vrací z rozvojových zemí, jako jsou Čína či Indie. Ty usilují o obdobný „ekonomický rozvoj“ a „růst“, a obhajují svou neochotu podřídit se ekologickým závazkům na základě stejné mantry „konkurenceschopnosti“. Dokud se EU nerozejde s ustáleným paradigmatem a zastaralými postupy, a nenabídne jasnou udržitelnou alternativu, jak může oponovat touze jiných částí světa následovat neudržitelnou cestu industrializace, která udělala z Evropy prosperující region?

Evropská unie tvrdí, že zná řešení environmentálních problémů dneška a že je bezpochyby nejaktivnějším regionálním aktérem, jenž se těmito otázkami vážně zabývá. Oficiální evropské orgány opakovaně podtrhují dosažený pokrok v ekologicky motivovaných opatřeních, a v poslední době navíc prezentují ekonomickou krizi jako příležitost pro novou vlnu takových opatření.

V posledním vydání Environment Policy Review z roku 2008, publikovaném EK, stojí:

Krize je klíčovou příležitostí udělat naši ekonomiku ,zelenější a položit základy nízkouhlíkového a zdroje efektivně využívajícího růstu. Jak recese ovlivňuje naše postupy, silnější environmentální opatření mohou napomoci oživení ekonomiky a konkurenceschopnosti EU. [EC 2009b: 12-13]

Obvyklým způsobem řešení problému, u nějž si myslíme, že známe řešení, je jeho úpornější implementace. Evropská unie vypracovala koncept „silné Evropy“ a jestliže jsme kýžené úrovně ještě nedosáhli, ukazuje to údajně na příliš nesystematické prosazování tohoto konceptu. Představa nedostatečně systematického prrístupu k uplatňování eko-opatření se ukazuje jako pravdivá, jak se celková proměna politiky v této sféře profiluje jako „nevyvážená ... (co se týče zpo̊sobů a nástrojů) a nerovnoměrně zaměřená (se zmírňováním téměř zcela zastiňujícím adaptaci)“ [Jordan et al. 2010: 259] a jak se její aktuální vývoj zdá být „nerovný s množstvím nových začátků a úprav spíše než jako neúprosný pokrok“ [Jordan et al. 2010: 259]. Tvrdíme, že př́ičinou tohoto problému je chybná volba základního cíle. Krize je prezentována jako šance pevněji lpět na ideji ekonomicky, politicky a kulturně mocné Evropy. Růst, ekonomická obnova a konkurenceschopnost; to jsou hnací motory ekonomické a environmentální integrace, která má na oplátku zajištovat vyšší kvalitu života občanů EU.

Jsme v situaci, kdy se globální ekologické výzvy stávají stále urgentnějšími, zatímco naše nástroje ke zmírňování jejich dopadů jsou stále méně účinné. „Na konci tisíciletí jsou environmentální trendy stále $\mathrm{v}$ režimu ztrát, včetně další degradace a fragmentace ekosystémů, ubývajících lesů, vymírání druhů, oslabující se regulace klimatu, škodlivých 
dotací apod." [Clement 2000: 3]. U př́ležitosti summitu G20 v Torontu v červnu 2010 dva nejvyšší zástupci EU vyjádřili své přání „zajistit silný a udržitelný růst“ [Securing strong and sustainable growth 2010]. Takové výroky vzbudí vždy zaručený zájem o způsob, jakým bude cíle dosaženo; novináři, politici a analytici se ptají, jak EU chce dosáhnout deklarovaných met. Tento přístup je rovněž tradiční v tom smyslu, že žádný účastník debaty nezpochybňuje výchozí představy o směru, kterým by se mělo jít.

Alternativou by pak bylo studovat EU na hlubší bázi, zaměřit se na význam výrazů jako jsou jistota, síla, udržitelnost nebo růst. V tuto chvíli je stabilita EU ohrožena v základech. Když přemýšlíme o budoucím vývoji, mohlo by být užitečné prověřit navrhovaná řešení ekonomické krize a jejich důsledky pro životní prostředí.

Je zřejmé, že současné směřování světového vývoje není dlouhodobě udržitelné, dokonce i když uznáme obrovský potenciál trhů a technologické inovace. Nové myšlenky a strategie budou třeba, máme-li zajistit lepší životní podmínky a mají-li být př́ležitosti pro rostoucí populaci ve světě sladěny se zachováním snesitelného klimatu a křehkých ekosystémůn, na nichž závisí veškerý život. Nová vize a směřování světového vývoje musí být přijaty, jestli má lidstvo obstát ve výzvách, které jej čekají. [The Club of Rome 2010]

Tato citace $\mathrm{z}$ webové stránky Římského klubu je příkladem myšlení, které jde za hranice standardní politické akce. Status EU je bezpochyby odlišný od pozice autonomní skupiny odborníků. EU je politickou entitou, regionálním týmem nezávislých hráčů. Její lídři se nicméně hlásí k závazku napomoci vytvoření „silné“ udržitelné komunity, která bude brát životní prostředí jako partnera a nikoliv pouze jako zdroj použitelný pro povzbuzení ekonomického růstu.

Když se ptáme po podstatě síly, jak je chápána ve většinovém diskursu v EU, zjištujeme, že navrhovaná ekonomická a environmentální opatření mohou přinést jedině konzervativní řešení. Př́ičiny obou tektonických změn jsou propojené a zasluhují si zvláštní pozornost. Jejich řešení nám však budou pravděpodobně z kulturního hlediska vzdálená.

„Dnešní lídři a podněcovatelé změn napříč institucemi stojí rozkročeni mezi dvěma světy: na jedné straně jsou konfrontováni s bezprecedentními výzvami 21. století, na straně druhé jsou vybaveni manažerskými strategiemi 20. století, které jsou nevhodné pro řešení dnešních problémů. Mezi těmito dvěma světy zeje propast, již je třeba přemostit.“ [Scharmer 2010: 2]

\section{Poděkování}

Článek vznikl v rámci projektu Globální ekonomická krize: Holistická analýza z multidisciplinárního hlediska za podpory Filozofické fakulty Univerzity Palackého v Olomouci a MŠMT ČR. 


\section{SEZNAM ZKRATEK}

CIA Ústřední zpravodajská služba USA

EEA Evropská agentura pro životní prostředí

EK Evropská komise

EP Evropský parlament

ER Evropská rada

ESF Evropské sociální fórum

EU Evropská unie

EU-27 evropská sedmadvacítka (všechny členské státy)

GBO Global Biodiversity Outlook

GEO Global Environmental Outlook

MMF Mezinárodní měnový fond

OECD Organizace pro hospodářskou spolupráci a rozvoj

WWF Světový fond na ochranu prrírody

\section{LITERATURA}

Baker, Susan. 1997. „The Evolution of the European Union Environmental Policy: From Growth to Sustainable Development." Pp. 91-106 in Susan Baker, Maria Kousis, Dick Richardson, Stephen Young (eds.). The Politics of Sustainable Development: Theory, Policy and Practice within the European Union. London, New York: Routledge.

Barroso, José Manuel. 2009. „From Kyoto to Copenhagen.“ Projev přednesený na Global Editors’ Forum. Kodaň, Dánsko, 9. 10. 2009. [online] [cit. 20. 10. 2010] Dostupný z: http://europa.eu/rapid $/$ pressReleasesAction.do?reference $=$ SPEECH/09/458\&format $=$ HTML\&aged $=0$ \&language $=$ EN\& guiLanguage $=$ en.

Barroso, José Manuel. 2010. „Europe of the Regions: Building Europe from the bottom up. “ Projev prednesený na Meeting for Friendship Among Peoples. Rimini, Itálie, 27. 8. 2010. [online] [cit. 18. 10. 2010] Dostupný z: http://europa.eu/rapid/pressReleasesAction.do?reference=SPEECH/10/403\&type =HTML.

Brown, Lester R. 2011. World on the Edge. New York: Norton and Company.

Burchell, Jon, Simon Lightfoot. 2001. The Greening of the European Union? Examining the EU's Environmental Credentials. London, New York: Sheffield Academic Press.

Buti, Marco. 2009. „Foreword.“ In European Commission. Economic Crisis in Europe: Causes, Consequences and Responses. Luxembourg: Office for Official Publications of the European Communities.

Central Intelligence Agency (CIA). 2010. The World Factbook: Europe: European Union. [online] [cit. 10. 10. 2010] Dostupný z: https://www.cia.gov/library/publications/the-world-factbook/geos lee.html.

Clement, Keith. 2000. Economic Development and Environmental Gain: European Environmental Integration and Regional Competitiveness. London: Earthscan.

Cole, Matthew A. 2000. Trade Liberalisation, Economic Growth and the Environment. Cheltenham, Northampton: Edward Elgar.

Collier, Ute. 1997. „Sustainability, subsidiarity and deregulation: New directions in EU environmental policy." Environmental Politics 6 (2): 1-23.

Council of the European Union. 2009. Council Conclusions on the Contribution of the Council (Environment) to the Spring European Council (19 and 20 March 2009). [online] [cit. 25. 10. 2010] Dostupný z: http://www.consilium.europa.eu/App/NewsRoom/related.aspx?bid=89\&grp=14848\&lang=EN\& cmsId $=339$.

Daly, Herman. 1996. Beyond Growth: The Economics of Sustainable Development. Boston: Beacon Press. „Editorial: Biodiversity Conference.“ 2010. The Asahi Shimbun 18. 10. 2010. [online] [cit. 20. 10. 2010] Dostupný z: http://www.asahi.com/english/TKY201010180266.html. 
Environment News Service. 2009. „Europe Will Miss 2010 Biodiversity Protection Target.“ 28. 4. 2009. [online] [cit. 20. 10. 2010] Dostupný z: http://www.ens-newswire.com/ens/apr2009/2009-04-28-01 .html.

„EU economic governance: the Commission delivers a comprehensive package of legislative measures." 2010. Europa.eu. [online] [cit. 25. 10. 2010] Dostupný z: http://europa.eu/rapid/pressReleasesAction .do? reference $=\mathrm{IP} / 10 / 1199 \&$ format $=\mathrm{HTML} \&$ aged $=\% 200 \&$ language $=\mathrm{EN}$ \&guiLanguage $=\mathrm{en}$.

European Commission (EC). 2007. „Communication from the Commission to the European Parliament, the Council, the European Economic and Social Committee and the Committee of the Regions on the Mid-term review of the Sixth Community Environment Action Programme." COM (2007) 225, Brussels, 30 April 2007.

European Commission (EC). 2008a. „From Financial Crisis to Recovery: A European Framework for Action." COM (2008) 706 final, Brussels, 29 October 2008.

European Commission (EC). 2008b. „A European Economic Recovery Plan.“ COM (2008) 800 final, Brussels, 26 November 2011.

European Commission (EC). 2009a. „Driving European recovery.“ COM (2009) 114 final, Brussels, 4 March 2009.

European Commission (EC). 2009b. 2008 Environment Policy Review. Luxembourg: Office for Official Publications of the European Communities. [online] [cit. 29. 10. 2010] Dostupný z: http://ec.europa .eu/environment/pdf/policy/epr_2008.pdf.

European Environment Agency (EEA). 2010. Assessing Biodiversity in Europe - the 2010 report. Luxembourg: Office for Official Publications of the European Communities. [online] [cit. 13. 10. 2010] Dostupný z: http://www.eea.europa.eu/ publications/assessing-biodiversity-in-europe-84.

European Union. 2007. Treaty of Lisbon Amending the Treaty on European Union and the Treaty Establishing the European Community, 2007/C 306/01, 13 December 2007.

European Social Forum (ESF). 2010. „Climate Justice Movements call in Istanbul.“ 5. 7. 2010. [online] [cit. 8. 10. 2010] Dostupný z: http://www.fse-esf.org/spip.php?article694.

Eurostat News Release 148/2010 - 6 October 2010. 2010 Eurostat Press Office.

Eurostat News Release 55/2010 - 22 April 2010. 2010 Eurostat Press Office.

Eurostat. 2009. Energy, transport and environment indicators. 2008 Edition. Luxembourg: Office for Official Publications of the European Communities.

Eurostat. 2010. Eurostatistics: Data for short-term economic analysis. Issue number 09/2010. Luxembourg: Publications Office of the European Union.

Global Biodiversity Outlook 3 - Executive Summary. 2010. Montréal: Secretariat of the Convention on Biological Diversity. [online] [cit. 20. 10. 2010] Dostupný z: http://gbo3.cbd.int/the-outlook/gbo3 /executive-summary.aspx.

Global Environment Outlook 04: Environment for Development. 2007. Nairobi: United Nations Environment Programme. [online] [cit. 12. 10. 2010] Dostupný z: http://www.unep.org/geo/geo4/report /GEO-4_Report_Full_en.pdf.

„Interim forecast September 2010: EU recovery progressing within an uncertain global environment.“ 2010. Europa.eu. [online] [cit. 25. 10. 2010] Dostupný z: http://europa.eu/rapid/pressReleasesAction. do? reference $=\mathrm{IP} / 10 / 1111$.

International Monetary Fund (IMF). 2010. World Economic Outlook (WEO): Recovery, Risk, and Rebalancing. Washington, DC: International Monetary Fund. [online] [cit. 8. 10. 2010] Dostupný z: http:// www.imf.org/external/pubs/ft/weo/2010/02/index.htm.

Jordan, Andrew. 2002. „Introduction: European Union Environmental Policy - Actors, Institutions and Policy Processes." Pp. 1-10 in Andrew Jordan (eds.). Environmental Policy in the European Union: Actors, Institutions, and Processes. London: Routledge.

Jordan, Andrew, Dave Huitema, Harro van Asselt. 2010. „Climate Change Policy in the European Union: An Introduction. “ Pp. 3-25 in Andrew Jordan, Dave Huitema, Harro van Asselt, Tim Rayner, Frans Berkhout (eds.). Climate Change Policy in the European Union: Confronting the Dilemmas of Mitigation and Adaptation? Cambridge: Cambridge University Press.

Jordan, Andrew, Dave Huitema, Harro van Asselt, Tim Rayner, Frans Berkhout. 2010. „Governing Climate Change in the European Union: Understanding the Past and Preparing for the Future.“ 
Pp. 253-275 in Andrew Jordan, Dave Huitema, Harro van Asselt, Tim Rayner, Frans Berkhout (eds.). Climate Change Policy in the European Union: Confronting the Dilemmas of Mitigation and Adaptation? Cambridge: Cambridge University Press.

Klare, Michael T. 2008. „The Economic Crisis and the Environment.“ The Huffington Post 17. 10. 2008. [online] [cit. 29. 9. 2010] Dostupný z: http://www.huffingtonpost.com/michael-t-klare/the-economic -crisis-and-t_b_135631.html.

Lenschow, Andrea. 2002. „Greening the European Union: An Introduction. “Pp. 3-21 in Andrea Lenschow (eds.). Environmental Policy Integration: Greening Sectoral Policies in Europe. London: Earthscan.

Phillips, Leigh. 2009. „Economic crisis producing huge drop in EU $\mathrm{CO}^{2}$ emissions.“ EU Observer. 3. 4. 2009. [online] [cit. 29. 9. 2010] Dostupný z: http://euobserver.com/885/27913.

Rankin, Jennifer. 2009. „Breaking butterflies upon a wheel of indifference?“ European Voice. 27. 8. 2009. [online] [cit. 25. 10. 2010] Dostupný z: http://www.europeanvoice.com/article/ imported/breaking -butterflies-upon-a-wheel-of-indifference-/65721.aspx.

Scharmer, Otto C. 2010. „The Blind Spot of Institutional Leadership: How To Create Deep Innovation Through Moving from Egosystem to Ecosystem Awareness." Draft paper pro World Forum Annual Meeting of the New Champions. Tianjin, Ćínská lidová republika, 13.-15. 9. 2010. [online] [cit. 29. 10. 2010] Dostupný z: http://www.ottoscharmer.com/publications/articles.php.

„,Securing strong and sustainable growth - President Barroso and President Van Rompuy set out EU goals for the G20 summit in Toronto.“ 2010. Europa.eu. [online] [cit. 30. 7. 2010] Dostupný z: http:// europa.eu/rapid/pressReleasesAction.do?reference=IP/10/784.

TEEB. 2010. The Economics of Ecosystems and Biodiversity: Mainstreaming the economics of nature: A synthesis of the approach, conclusions and recommendations of TEEB. [online] [cit. 21. 10. 2010] Dostupný z: http://www.teebweb.org/InformationMaterial/TEEBReports/tabid/1278/language/en-US/Default. aspx.

The Club of Rome. 2010. „A New Path for Development.“ [online] [cit. 29. 10. 2010] Dostupný z: http:// www.clubofrome.org/eng/new_path/.

The Economics of Ecosystems and Biodiversity: An interim report. 2008. European Communities.

Wissenbach, Ilona, Timothy Heritage. 2008. „EU agree to change treaty, create crisis safety net.“ Reuters. 29. 10. 2008. [online] [cit. 25. 11. 2010] Dostupný z: http://www.reuters.com/article/idUSL DE69S0ZE20101029.

World Wildlife Fund (WWF). 2010. Making the EU Budget Work for EU Citizens. Brussels: WWF. [online] [cit. 29.10.2010] Dostupný z: http://wwf.panda.org/about_our_earth/all_publications/?194993 /Making-the-EU-Budget-work-for-EU-Citizens.

\section{SUMMARY}

Europe, currently integrating within the European Union, is facing interrelated crises in the spheres of politics, culture, economics and environment. How is the development in these areas connected and how to approach the issue from a cultural perspective? Our hypothesis is that the global economic crisis unraveling simultaneously with ecological degradation is caused by a false understanding of the concept of "power". The attempts to create a strong, globally successful region are primarily based on the idea of competitiveness and economic growth. Academics, politicians, bureaucrats and journalists follow developmental trends in, for example, China, fearing that Europe loses its leading position in the world. However, in reality the slowing of economic growth brings hope for longer and better life of citizens compared with the rapidly developing but highly polluted countries. Green, slowly expanding economy is more flexible, viable and also stable than the one which is growing at a galloping pace. The traditional Western economic competitiveness (which is a struggle of rivaling economic forces) is incompatible with principles which Europe is currently promoting under the banner of ecological sustainability. The need to mitigate the consequences of the recession is met by tweaking the system, which in its core is at the very best neutral towards the environment, if not detrimental to it. As the EU builds its new vision on the environmental-friendly foundation and positions itself as a leading actor in green politics, the basic assumptions about the world remain ecologically unsustainable. If we take a closer look at the essence 
of power as conceived by the majority, it becomes clear that power is a synonym of growth and that small can be beautiful, but never strong. The causes of drastic economic and environmental changes are cultural assumptions, which need to be approached comprehensively. However, our society fails to do so, partial solutions adopted are insufficient and the need to work out a comprehensive strategy lingers. The concept of power in its traditional Western rationalist spirit becomes even more dangerous when its logic is accepted by other world regions striving to achieve the European standard of life. The current model of economic development, upon which a thin layer of ecological consciousness is superimposed, links strength with trust in the existing social order, stability, growth and innovation aimed at increasing competitiveness. "Strong" Europe, mantra of the European political elite, is a Europe returning to conservative anthropocentric values and cultural domination (of the West over the rest of the world, of a human being over nature). We are arguing for a revision of the concept of "strength" and for a shift away from aiming at material goals. Despite frenetic measures adopted to save the economy and the ambitious environmental agenda of the EU, in neither of these spheres the progress is satisfactory. Thus, if the current crisis of the Western society has a cultural foundation, one cannot progress by making isolated steps to prop the aging vision of the world, but it requires courage to open oneself to a radical cultural alternative. 